\title{
Study of Personality Traits of Tobacco-Users and Non-Users
}

\section{among Students}

\author{
Dr. Ruturaj H. Jaiswal*
}

\section{ABSTRACT:}

Tobacco use is a multi- dimensional and a worldwide problem with an alarming increase in its incidences. Adolescence continuing use of tobacco is major public health problem in India. The present study was attempted to study the personality traits of tobacco users (TU) than tobacco non-users (TNU) students. The purposive sampling method was adopted to select the sample. The sample consisted of 100 subject with tobacco users $(n=50)$ and non-users $(n=50)$ were selected from different schools and colleges of Jamnagar city of Gujarat state. The tools used were Eysenck's Personality Inventory, gujarati version. Student-T test was used to analyses the data. The present study revealed that there is significant difference between student tobacco users and non-users on Neuroticism and Extraversion dimensions of personality. Student tobacco users score higher on both dimensions of personality than non-users. Conclusion: when tobacco prevention and intervention program are developed, these personality traits should be consider in addition to physiological aspects.

Keywords: Personality, tobacco user, tobacco non-user

\section{INTRODUCTION}

Tobacco is the most widely distributed and commonly used drug in the world, today. Tobacco use usually begins in adolescence, the time for discovery, challenge and experimentation. Based on the current trends, the WHO, predicts that by the year 2020, tobacco use will cause more than 10 million deaths per year (Warren et al, 2008). The risk of tobacco use are highest among those who start early and continue its use for a long period (Sinha, 2002).

As per Bate et al (2009), and Tesering et al (2010), each day in India, an estimated 5500 youth initiate tobacco use, contributing to predictions that by 2020, tobacco will account for $13 \%$ of all death in India. According to Global Youth Tobacco Survey (GYTS 2003), in Gujarat, tobacco usage is $29.3 \%$ among the boys and $4.3 \%$ among the girls of class 8 to 10.Two in every five daily tobacco users age 20-34 had started using tobacco daily before attaining the age of 18 . (GATS-INDIA, 2009-2010). The number of adolescence continuing to use tobacco in any form remains the major public health problem in India.

\footnotetext{
*Clinical Psychologist, Hospital for Mental Health, Jamnagar, Gujarat
}

(C) 2014 R Jaiswal; licensee IJIP. This is an Open Access Research distributed under the terms of the Creative Commons Attribution License (http://creativecommons.org/licenses/by/2.0), which permits unrestricted use, distribution, and reproduction in any Medium, provided the original work is properly cited. 
Almost half of the students, both from schools and colleges were aware about the close association between tobacco/ gutkha and oral cancer (Parwal et al), and other health consequences of tobacco consumption, many young people start tobacco use during adolescence. In India, government and many NGOs run program for tobacco control and prevention, despite of ban on smoking, it has shown limited impact on smoking habit (Bhatia et al, 2009).

The failure of anti-tobacco use program may have been inevitable by not considering intrinsic psychological factors due to the prevailing assumption that young adults are driven solely by extrinsic and social factors when choosing to smoke or mot to smoke (Lynch, 1995; O'Toole et al, 2001). Tobacco use is an interactional phenomenon, where in, apart from the tobacco or a toxic agent and social environment, the personality characteristics of the individual also play an important role.

There are several studies in the literature associating tobacco use and personality characteristics. Many studies found that smokers are more extroverts ( Cattell et al, 1967; Smith, 1969; Coan, 1973, Lipkus et al,1994;).Smokers are more aroused and potentially irritated or angered more easily than non-smokers(David,1988). According to Coan(1973), smokers tend to be more extroverted, more distress prone, more liberal, more open to experience and more inclined to favor spontaneity than non-smokers. Berger (1971) reported that smokers revealed a preference for excitement and admitted to behavior conflicting with authority or social more. Cherry and Kiernan (1976) found that extroverts were more likely to smoke than introverts. In the recent past, Kara \& Jennifer (2008) reported that smokers would have higher score on extraversion than non-smokers. On the other hand few researchers not found difference on extraversion (McCrae et al, 1987; Sijuwola, 1989).

One study on same issue indicate that person who had lifetime diagnosis of tobacco dependence according to ICD-10, DSM-4 or FTQ criteria were scored significantly higher on neuroticism scale of Eysenck than non- dependent ever smokers (Kawakami et al, 2000). There are some studies, which showed strong relation between smokeless tobacco use (Charles et al, 1999; John et al, 1993), smoker (Kara \& Jenifer, 2008) and extroversion and neuroticism. Cherry and Kiernan (1976) and McCrae et al (1987) recorded that high N score were found to be more likely to smoke than those with low score. Recent past, Joseph (2010) and Julie(2008) reported relationship between smoking and depression. On the other side, few researchers reported that $\mathrm{N}$ was not related to smoking (Parkes, 1984). Sijuwola (1989) concluded that no significance difference between tobacco users and non-users on $\mathrm{N}$ scale of the Eysenck Personality questionnaire. Most of researchers suggest that further studies are required, comprising different populations from different geographic, social and cultural contexts, in order to provide more conclusive data.

As per above observation, purpose of the present study was to investigate the personality traits of students who consume tobacco, which may contribute to control and preventive and treatment 
activities in the future. And it would be a kind of contribution towards the development and progress of our society and nation.

\section{OBJECTIVE}

Objective of the present study is to find whether there is a significant difference in personality traits of students who are tobacco user and non-user.

\section{HYPOTHESIS}

For the above mentioned objective, following null hypotheses was formulated:

1. There will be no significance difference between student tobacco users and non-users in relation to their personality traits.

\section{METHOD}

\section{Sample:}

The present study was conducted on a sample of 100 students among which 50 are tobacco users and 50 are non-users, with the age range of 16 to 20 years. The purposive sampling method was used to select sample from Jamnagar District of Gujarat.

\section{Tools:}

Gujarati adaptation of Eysenck's Maudsley Personality Inventory was used for the present study. It was developed by Dr. D. J. Bhatt. This test can be used as a group and an individual test, for persons of ages 15 to 16 and above. It consist 48 items, which measures two personality dimension ,namely, Neuroticism - Stability (N) and Introversion - Extraversion (E).24 items or question for each dimension. The test gives a maximum score of 48 on $\mathrm{N}$, and also 48 on $\mathrm{E}$ dimension of personality. High score indicate higher level of neuroticism and extraversion. The reliability coefficient by test-retest method for $\mathrm{N}$ and $\mathrm{E}$ scale is 0.76 and 0.74 respectively, and by split-half method 0.85 and 0.96 respectively. Bhatt (1999) reported high validity of gujarati version of MPI.

\section{Procedure:}

Initially, the participants were contacted and their willingness to participate in the study was sought. Preliminary information like age, gender, education, tobacco use or not etc. were collected. Then, Maudsley personality inventory was administered on them. On average respondents required 15 to 20 minutes to complete the inventory. After the collection of data, the data obtained were scored individually for each subject. In order to fulfill the objective of the study and to prove the hypothesis formulated, the scores obtained were then analyzed by using mean, standard deviation and t-test. 


\section{RESULT AND DISCUSSION}

Table: 1 Mean, Standard Deviation and T-ratio of MPI scores of

50 Tobacco users (TU) and 50 Non-users (TNU) students

\begin{tabular}{|c|c|c|c|c|c|}
\hline MPI traits & Group & Mean & S.D. & T-value & $\begin{array}{c}\text { Level of } \\
\text { Significance }\end{array}$ \\
\hline Neuroticism & $\begin{array}{l}\text { TU(50) } \\
\text { TNU(50) }\end{array}$ & $\begin{array}{l}29.82 \\
17.88\end{array}$ & $\begin{array}{l}8.95 \\
8.64\end{array}$ & $+6.78 * *$ & 0.01 \\
\hline Extraversion & $\begin{array}{l}\text { TU(50) } \\
\text { TNU(50) }\end{array}$ & $\begin{array}{l}30.1 \\
28.0\end{array}$ & $\begin{array}{l}3.89 \\
5.35\end{array}$ & $2.24 *$ & 0.05 \\
\hline
\end{tabular}

$* \mathrm{P}<0.05 ; * * \mathrm{P}<0.01$

The above table shows there is a significant difference between the mean scores of tobacco user and non-user students on neuroticism and extraversion dimension of personality. Tobacco user students have higher score on Neuroticism as compared to non-users. Eysenck (1975), describes high $\mathrm{N}$ scorer as being an anxious, worrying individual, moody and frequently depressed, he is overly emotional, reacting too strongly to all sorts of stimuli, and find it difficult to get back on an even keel after each emotionally arousing experience. His strong emotional reactions interfere with his proper adjustment, making him react in irrational, sometimes rigid ways. (Hall et al, 2007, p.371). The possible reason of this finding may be those who score high on $\mathrm{N}$ may smoke to reduce tension and anxiety (Eysenck, 1980).

The findings of present study support the few earlier studies which showed that tobacco users scored higher on neuroticism in comparison to non-users (Kara \& Jenifer, 2008; Kawakami et al, 2000; Charles et al,1995; John et al;1993; McCrae et al, 1987; Cherry \& Kiernan,1976).Joseph et al (2010) also found cause and effect relationship between smoking and depression. Julie et al (2008), also suggest that smoking increase the risk of major depressive disorder. And contradict previous studies of Parkes (1984) and Sijuwola (1989) who reported no significance difference on $\mathrm{N}$ scale.

Table-1 also shows that Tobacco user students have higher score on Extraversion as compared to non-users. According to Eysenck, extravert is sociable, like parties, has many friends, needs to have people to talk to, and does not like reading or studying by himself; they craves excitement. Takes chances, often stick his neck out, acts on the spur of the moment, and is generally an impulsive individual; and generally likes change; he is care free, easy-going, optimistic, and likes to laugh and be merry; prefers to keep moving and doing things, tends to be aggressive and lose his temper easily; altogether his feelings are not kept under tight control, and he is not always a reliable person (Hall et al,2007). It may be due to person scoring high on Extraversion may smoke because they seek stimulation (Eysenck, 1980).

The findings of present study support the previous findings which found tobacco users are more extroverts (Cattell et al,1967; Smith,1969; Coan 1973, Cherry \& Kiernan,1976; Lipkus et al, 1994; Kara \& Jennifer,2008), more aroused and angered (David,1988), preference for excitement(Berger,1971). And contradict previous studies of McCrae et al (1987), Sijuwola (1989) which concluded that no difference between tobacco users and non-users on extraversion. In summary, the present researcher feels that the above mention personality traits of young generation should be given emphasis for anti tobacco prevention and intervention program in 
addition to physiological aspects. Adolescence and students should be the target group for the anti tobacco awareness program because they are the future adult who will develop and represent our nation.

\section{REFERENCES}

1. Bate, S.L., Stigler, M.H., Thompson, M.S., Arrora, M., Perry, C.L., Reddy, K.S., et al (2009). Psychosocial mediators of a school based tobacco prevention program in India: Result from the first year of project MYTRI. Preventive Science.10:116-28

2. Bhatia, V., Puri, S., Kaur, A., Vijayawwt, M., (2009). Impact of ban of smo0king in first smoke free city of Chandigarh in India. Indian Journal of Cancer.2010:47:109-210.

3. Bhatt, D.J.(1999).Manual of the Maudsley Personality Inventory.Viral prakashan, Amadavad.

4. Berger, Emanuel M.(1971). MMPI item differences between smoker and nonsmoker college freshman males. Journal of counsulting and clinical psychology, Jun, 36(3):446.

5. Cattle, R.B., Krug, Samuel.(1967). Personality factor profile peculiar to the student smoker. Journal of counseling psychology. 14(2):116-121.

6. Charles, D.S., John, P.F., G Ken Goodrick and Eric C Rehesier (1999).Personality characteristics of users of smokeless tobacco compared with cigarette smokers and nonusers of tobacco products. Personality and Individual Differences, 19(4): 439-448.

7. Cherry, N., \& Kiernan, K.(1976). Personality scores and smoking behavior. A longitudinal study. British J Preventive Social Medicine.Jun; 30(2):123-31.

8. Coan, Richard W. (1973). Personality variables associated with cigarette smoking. Journal of Personality and social psychology. 26(1):86-104.

9. David, G.G. (1988). EEG and personality difference between smokers and non-smokers. Personality and Individual differences. 9(3): 659-665.

10. Eysenck, H. J. (1980). The causes and effects of smoking. Beverly Hills, CA7 Sage.

11. Hall, G.S., Lindzey, G., Campbell, J.B. (2007). Theories of Personality (4 ${ }^{\text {th }}$ edt.) p.37071, John Wiley publication: Noida.

12. John, D.F., Andrew, S.J., William, G.S. Jr.,G Harely Hartung, Tinker D Murry, Antonio M Gotto Jr.(1993). Psychological profile of college students who use smokeless tobacco. Addictive Behaviors. 18(2): 107- 116.

13. Joseph M. Boden, David M. Fergusson, and L. John Horwood(2010) Cigarette smoking and depression: tests of causal linkages using a longitudinal birth cohort. The British Journal of Psychiatry (2010) 196: 440-446.

14. Julie A. Pasco, Lana J. Williams, Felice N. Jacka, Felicity Ng, Margaret J. Henry, Geoffrey C. Nicholson, and Mark A. Kotowicz, Michael Berk,(2008) Tobacco smoking as a risk factor for major depressive disorder: population-based study The British Journal of Psychiatry;193:322-326.

15. Kara Hames; Jennifer SP. (2008) Personality and social differences of cigarette smoking among college students.USC Upstate Undergraduate Research Journal(Spring); volume 1: 7-12. 
16. Kawakami, N., Takai, A.,Takatsuka, Shimizu H.(2000).Eysenck's personality and tobacco/nicotine dependence in male ever smoker in Japan. Addictive Behaviors. 25(4): 858-91.

17. Lipkus, I.M., Barefoot, John, C., Williams, Redford, B., Siegler, Hene, C. (1994). Personality measure as predictors of smoking initiation and cessation in the UNC alumni Heart Study. Health Psychology.13 (2):149-155.

18. Lynch, P. (1995). Adolescent smoking: An alternative perspective using personal construct theory. Health Education Research, 10, 95-106.

19. McCrae, R.R., Costa, P.T. Jr., Bosse, R.(1987). Anxiety, extraversion and smoking. British J Social Clin. Psychology. Sep; 17(3): 269-73.

20. O'Tool, T.P., Torabi, M.R. (2001). A comparison of personality types considering tobacco use. American Journal of Health Studies. Available on :http://findarticles.com /p/articles/mi_m0CTG/is_1_17/ai_ai83662682/

21. Parkes, K.R.(1984). Smoking and the Eysenck personality dimensions: an interactive model. Psychological Medicine.Nov.;14(4): 825-34.

22. Parwal, A.B., Mukherjee, short article. Guthka and Tobacco consumption and awareness of their health hazards among school and college students in Gujarat.

23. Sijuwola, O.A.(1989). Dimension of personality and smoking behavior. African J Med Sci.Jun 18(2): 105-8.

24. Sinha, D.N. Report on the result of the Global youth tobacco survey in U.P., India 2002. (http://www.searo.who.int/LinkFiles/GYTSR Uttarpradesh_2002.pdf.)

25. Smith, Gene, M. (1969).Relationship between personality and smoking behavior in preadult subject. Journal of counseling and Clinical Psychology. 33(6):710-715.

26. Tesering, D., Pal, R., Dasgupta, A. (2010). Licit and illicit substance use by adolescent student in eastern India: Prevalence and associated risk factors. Journal of Neuroscience Rural practice. 1: 76-81.

27. Warren, C.W., Jones, N.R., Peruga, A., Chauvin, J., Baptiste, J., Costa de Silva, et al.(2008). Global youth tobacco surveillance,2000-2007.MMWR surveillance summary 2008; 57:1-28 